\title{
Redes, ativismo e mobilizações públicas. Ação coletiva e ação conectada
}

\author{
Isabel Babo \\ Universidade Lusófona do Porto \\ E-mail: isabel.babo.iblegmail.com
}

\begin{abstract}
Resumo
Com o uso generalizado das redes sociais digitais surgiram novas práticas comunicacionais e de mobilização coletiva, assim como novas configurações de agir e se manifestar em público. Neste texto, questiona-se onde começa ou acaba a ação coletiva em relação à ação conectada (connective action; Bennett e Segerberg, 2012), admitindo-se que estas modalidades ou lógicas de ação podem mitigaremse, num regime híbrido. Para tal, começa-se por colocar a comunicação como ação e participação, pas-

para, de seguida, encarar a ação conectada na rede. Pretende-se discutir as fronteiras permeáveis entre a ação conectada e a ação coletiva, com referência ao movimento "Que se lixe a Troika", que emergiu nas redes sociais digitais, e às manifestações do dia 15 de Setembro de 2012 e de 2 março de 2013, indagando-se o ativismo em rede e a participação na rua. Em suma, trata-se de questionar se uma ação conectada, que congregue vários utilizadores, pode constituir uma ação coletiva.
\end{abstract} sando à ação coletiva, ação situada e ação pública,

Palavras-chave: ação coletiva; ação conectada; ativismo em rede; mobilização pública.

\section{Networks, activism and public mobilizations. Collective and connective action}

\begin{abstract}
With the common and dominant use of digital social networks, new communication and collective mobilization practices emerged, as well as new configurations of acting and manifesting in public. In this essay, we ask where collective action begins and ends in relation to the connective action (Bennett and Segerberg, 2012), admitting that these modalities or logics of action can be mitigated, in a hybrid regime. To do this, we begin by understanding communication as both action and participation, then examine

collective, situated and public action and finally consider the connective action. We intend to discuss the permeable boundaries between connective action and collective action, with reference to the movement "Que se lixe a Troika" ("To hell with troika!"), which emerged on digital social networks and had protests on the street in the 15th September 2012 and the 2th March 2013. At the same time, the network's activism and the mobilization in the street are questioned. Therefore, the purpose is to question if the
\end{abstract}

Data de submissão: 2018-06-20. Data de aprovação: 2018-09-02.

A Revista Estudos em Comunicação é financiada por Fundos FEDER através do Programa Operacional Factores de Competitividade - COMPETE e por Fundos Nacionais através da FCT - Fundação para a Ciência e a Tecnologia no âmbito do projeto Comunicação, Filosofia e Humanidades (LabCom.IFP) UID/CCI/00661/2013.
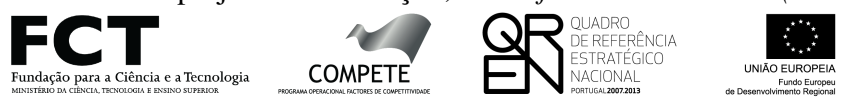

\密离

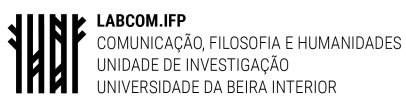


digitally networked action or the connective action, which brings together several users, can constitute a collective action.

Keywords: collective action; connective action; network activism; public mobilization.

$\mathrm{O}$ uso generalizado das ligações electrónicas introduziu novas práticas comunicacionais e de mobilização coletiva. As redes sociais digitais, enquanto meios de comunicação e informação, não instituíram somente novas formas de comunicar e informar, mas reverteram-se igualmente em meios de partilha e de mobilização, podendo desencadear a ação pública. Possibilitam recrutar uns e outros, convocar ações no espaço público e, in situ, dar conta das ocorrências. Aqueles que conduzem uma ação em comum, se manifestam e expressam em público, estão simultaneamente conectados em rede, ligando-se a outros de modo atópico e sem fronteiras, difundindo apelos à participação, informações, comentários, imagens, sons, etc. Nessa medida, ao mesmo tempo que as modalidades de mobilização e de disseminação das mensagens e informações se expandem, é a ação - individual e coletiva - que se dota de novos regimes de publicitação, visibilidade e ativismo.

Estes fenómenos suscitam diversas questões, entre as quais indagar as transformações que estão a ocorrer nas práticas de mobilização, impelidas pelos novos dispositivos tecnológico-comunicacionais, assim como nas modalidades de ação e de participação, sobretudo ao nível da ação coletiva que é incorporada pela nova lógica comunicativa assente na interatividade, reprodutibilidade, instantaneidade e atualização contínua. Nas redes sociais digitais conectadas (internet e dispositivos móveis de conexão: tablet, smarthphone, ipod, etc.) vigoram possibilidades ilimitadas de comunicação, de produção e recepção, de expressão, de personalização (weblogues, Facebook, Twitter, Instagram, etc.), de disseminação de mensagens, sons e imagens.

As manifestações e os movimentos de protesto das revoluções árabes (de $2010 \mathrm{em}$ diante), Geração à Rasca (Portugal, 2011), Occupy Wall Street (2011, que se propagou por outras cidades do mundo), Movimiento 15-M ou Indignados (Espanha, 2011), Que se Lixe a Troika (2012, em cidades portuguesas e outras), Movimento Passe Livre (2013) e Não vai ter copa (contra a Copa do Mundo de 2014, no Brasil), utilizaram as ligações tecnológicas para protestar, mobilizar, convocar adesões e desencadear ações coletivas no espaço público. Se tiveram origem nas redes, foi no espaço público que desembocaram, lugar onde se desenrolaram as ações coletivas que, por sua vez, granjearam visibilidade nas redes, em direto e em reprodutibilidade (Twitter, Facebook, Instagram, YouTube, etc.), assim como foram divulgadas e comentadas nos media tradicionais (o que convém não esquecer, quando se reconhece o papel da televisão, como a AL Jazeera ou a BBC, por exemplo, na designada primavera árabe). Pode dizer-se que, com o uso das novas tecnologias da comunicação, não somente as modalidades de mobilização se alteraram, mas também as formas de ação coletiva (e de ação pública), dando lugar a novas configurações de agir e se manifestar em público. Importa, por isso, colocar a questão de perceber onde começa e/ou acaba a ação coletiva em relação à ação conectada (connective action; Bennett e Segerberg, 2012), admitindo-se que, na rede, se está ao nível das ligações e ação conectada, podendo, contudo, estas modalidades ou lógicas de ação mitigarem-se, num regime híbrido. 
A partir da caracterização da ação coletiva e da ação conectada, surgem diversas interrogações, tais como: pode uma ação conectada que congregue vários utilizadores constituir uma ação coletiva? e será a comunicação electrónica, em que todos se ligam a todos, lugar para a formação de coletivos?

Começarei por colocar a comunicação como ação e participação, passando, depois, às questões dos coletivos, da ação coletiva, da ação situada e da ação pública, para, de seguida, encarar a ação conectada na rede e discutir as fronteiras permeáveis entre a ação conectada e a ação coletiva, reportando-me ao movimento "Que se lixe a Troika" e às manifestações do dia 15 de Setembro de 2012 e de março de 2013. Por último, indagarei a ação digital em rede e o netativismo, a participação nas redes e na rua.

\title{
COMUNICAÇÃO, AÇão COLETIVA E ação conectada
}

\section{Comunicação, ação e participação}

Para tratar a comunicação como participação recorremos a Dewey, para quem a comunicação é um processo de participação, associação e significação:

\begin{abstract}
"Comunicar qualquer coisa não é anunciar mesmo se é dito com enfâse e barulho. A comunicação é o processo de criação de uma participação, que torna comum o que foi isolado e singular; e uma parte do milagre realizado é que, sendo comunicado, a transmissão do sentido dá corpo e forma à experiência tanto daqueles que falam como daqueles que escutam.

Os homens estão associados de várias maneiras. Mas a autêntica forma de associação verdadeiramente humana que não se reduza a um ajuntamento gregário para se manter aquecido e se proteger, ou a um simples expediente para agir no exterior, assenta na partilha das significações e dos bens que a comunicação permite" (Dewey, 2010 b: 399).
\end{abstract}

A comunicação implica indivíduos em interação, produção de significação e participação. Dewey, em Experience and Nature ${ }^{1}$, considera que a comunicação é uma atividade que se liga às interações sociais nas quais há produção de sentido e que é da ordem da cooperação e da experiência partilhada ${ }^{2}$. A comunicação é uma atividade indissociável de uma situação e de uma temporalidade constituída das experiências anteriores e ulteriores e a significação associa-se à experiência comum e à percepção das consequências da atividade. Por isso, compreender é também antecipar em conjunto ${ }^{3}$, ao mesmo tempo que o resultado das interações anteriores armazena significações graças às quais se apreendem e compreendem as ocorrências em curso ou futuras (cf. Dewey, 2010 b: 441).

O sentido emerge na intercomunicação e reside numa comunidade de participação, e as significações comuns e mutuamente transmitidas constituem, simultaneamente, mediações práticas que permitem a partilha de ideias, sentimentos e atividades. Logo, tanto a identidade pessoal,

1. Ver capítulo V, "Nature, Communication and as Meaning", 1925, 1929.

2. "It is communication; the establishment of cooperation in an activity of each is modified and regulated by partnership" (Dewey, [1925] 1929: 179).

3. Como assevera Dewey, "To understand is to anticipate together, it is to make a cross-reference which, when acted upon, brings about a partaking in a common, inclusive, undertaking" (1929: 178-179). 
quanto as atitudes, as opiniões, os conhecimentos, as preferências, os interesses comuns derivam das consequências das interações sociais, que propiciam a individuação e a socialização. Dewey (1929) enfatiza a importância da conversação na qual há troca social, dar e receber, permutar experiências, individuação e socialização. A conversação social possibilita o comprometimento das pessoas na conversa, ouvirem-se uns aos outros e a emergência de interesses, problemas e sentimentos comuns.

A comunicação vincula-se a uma comunidade de ação em que a compreensão comum se liga ao meio cultural, aos hábitos sociais, às formas de colocar as coisas em comum (pensamentos, ações, problemas, sentimentos, crenças), aos costumes e às instituições, à luz de um contexto e de uma situação (i.e. o quadro social, as expectativas). É, por isso, que as significações se constroem em conjunto, com a linguagem comum, a cooperação de uns e outros e as ações e afecções recíprocas. Por sua vez, as significações comuns e mutuamente transmitidas possibilitam a partilha das atividades, permitem estabelecer laços sociais - o que favorece a adesão a interesses, sentimentos, cognições, normas e ações comuns - e, como advogou Dewey (2010 a: 248), possibilitam que uma atividade coletiva se converta numa comunidade de interesses ${ }^{4}$. É, portanto, no contexto da comunicação e da ação em comum que a formação de interesses partilhados tem lugar.

Evidencia-se, deste modo, de um ponto de vista pragmatista, que a linguagem e a comunicação são atividades que desempenham uma função prática e que devem ser encaradas como terreno da ação conjunta. Esta perspetiva permite esclarecer a dimensão de participação da ação, ou a ação partilhada, mas também colocar a questão da ação coletiva e da situação.

\section{A ação coletiva}

Como Dewey (2010 b) refere em relação à experiência, a dimensão coletiva desta não decorre de uma adição de experiências individuais. Do mesmo modo, a ação coletiva não consiste na associação de ações individuais que convergem num dado momento ou lugar, mas resulta de um conjunto de ações concertadas e coordenadas que se organizam e desenvolvem em torno de interesses comuns. Isto não significa que a ação coletiva se reduza a uma ação conjunta racional no que respeita aos fins, em que as expectativas constituem meios para atingir racionalmente um fim. Reportamo-nos à tipologia da ação social de Max Weber (Economia e Sociedade, 1922), em que a ação "instrumental" racional é um tipo de ação, a par da ação racional no que respeita os valores (ação "axiologicamente racional" que realiza uma crença, moral ou religiosa, por ex., segundo valores), da ação afetiva (determinada por uma sentimento ou uma emoção) e da ação segundo a tradição (realizada de acordo com os usos e costumes, regida por hábitos e crenças). Na base desta classificação está a distinção que Weber propõe entre a "racionalidade por relação a um fim", ou racionalidade teleológica, que consiste na racionalidade utilitária e instrumental e na racionalidade da escolha, e se refere à utilização dos meios adequados aos fins em vista (frequente na ação económica e na política), e a "racionalidade por relação aos valores" que consiste numa racionalidade axiológica ou na orientação da ação segundo valores. Embora se deva salientar que pode uma mesma ação combinar em graus diversos diferentes tipos (por exemplo, a racionalidade

4. O interesse, como o desejo, é, em Dewey, um modo de comportamento, uma maneira de agir. 
da escolha de um fim ser orientada por valores ou por usos e costumes). Ora, também a ação coletiva não tem de ser encarada necessária ou predominantemente como uma ação racional orientada por fins e, à semelhança de Weber, pode entender-se que ela pode combinar razões, fins, valores, emoções. Se convocarmos Dewey, que combateu o pensamento dicotómico, compreender-se-á que uma ação conjunta pode englobar aspetos cognitivos, afetivos, normativos e/ou práticos, de acordo com interesses comuns, sustentados em conhecimentos, sentimentos, emoções, normas, convenções, desejos, vontades ou expectativas.

Entenda-se que a ação coletiva tem como suportes a comunicação e as significações partilhadas, assim como a atenção conjunta, que permitem o acordo sobre um interesse ou vontade comum. Como Dewey defendeu, em The Public and its Problems (1927), a propósito dos coletivos que são os públicos, a comunicação é a condição prévia da participação e da formação dos públicos, pois na base destes estão as significações comuns partilhadas que estabelecem laços sociais e que podem converter uma ação conjunta numa comunidade de interesses:

"As significações comuns estabelecem novos laços e convertem uma atividade coletiva numa comunidade de interesse e de esforço: pode surgir uma vontade geral" (Dewey, 2010 a: 248).

A comunicação pública garante significações partilhadas, a formação conjunta das experiências e o surgimento de uma comunidade de ação em torno de um interesse comum. Logo, o interesse e a vontade comum desenvolvem-se na comunicação e na ação. Donde, e no mesmo sentido em que Quéré afirma que a intencionalidade tem uma realização prática e, nessa medida, não faz sentido falar da intenção de uma ação senão por relação à sua realização prática ${ }^{5}$, o interesse também se liga a uma significação e àquilo que o realiza (à comunicação e à ação). Em torno de uma atividade conjunta podem formar-se interesses comuns que, por sua vez, sustentam a ação coletiva, da qual advirá um coletivo como seu sujeito. Este, mais do que anteceder a ação, antes emerge à medida do seu desenvolvimento. O que será dizer que o sujeito coletivo se liga indissociavelmente à ação conjunta, resultando dela, e não precedendo-a. Por sua vez, a ação coletiva remete para atores coletivos, enquanto sujeitos dessa ação e que estão ligados ao carácter coletivo da mesma, implicando participação e cooperação.

Como em Dewey $(1927 ; 2010$ a), a comunicação é a condição prévia da participação e da formação do público, que não é dado antecipadamente, antes emerge através das interações entre as pessoas que se constituem como investigadores, que se mobilizam e que participam. Do mesmo modo, a ação coletiva desenvolve-se a partir de uma comunicação comum, de significações partilhadas e de uma atenção conjunta que possibilitam a constituição de interesses ou vontade comuns, regulados por valores e pelas significações.

F. Dubet (1990: 190) observa que na ação coletiva se encontram "lógicas de integração, estratégias de defesa de interesses e a mobilização de um universo de valores e de convicções". Contudo, o carácter partilhado de uma ação pode ir das "condutas sociais organizadas" (F. Dubet, 1990), aos movimentos sociais estruturados e institucionalizados, como o movimento operário, às "condutas coletivas efémeras e pouco controladas nas quais os atores constroem as suas identidades e os seus modos de participação social" (F. Dubet, 1990: 190). O que, de algum modo,

5. "L'action et l'intention s'appartiennent réciproquement, à la fois sur le plan conceptuel et sur le plan pratique" (Quéré, 1990: 98). 
esclarece que a tarefa de compreensão da ação coletiva estará facilitada se for tomado como objeto de análise um movimento social, pela sua própria natureza. Como Benford e Hunt, que aplicaram a frame analysis aos movimentos sociais, tornaram claro, o carácter coletivo do movimento social é-lhe intrínseco.

\begin{abstract}
"Nos caso dos movimentos sociais, o caráter coletivo constitui uma dimensão essencial da sua identidade. (...) R. Hunt (1991: 255) define o caráter coletivo como 'uma componente da identidade coletiva que mantém um sentido da unidade e que inclui um complexo de traços comportamentais, cognitivos e morais imputados pelos participantes quer a uma organização tomada como um todo, quer a equipas particulares que a constituem'. O carácter coletivo surge assim como uma constelação de atributos conferidos ou reivindicados, dizendo respeito à racionalidade ou à ética, aos afectos ou à 'moral' de um grupo" (Benford e Hunt, 2001: 174).
\end{abstract}

$\mathrm{Na}$ esteira destes autores, o tratamento da ação coletiva coaduna-se com uma análise do seu enquadramento mediante o conceito de frame (ou mediante a atividade de enquadramento; framing), no sentido da análise dos quadros (frame analysis, Goffman, 1974; frame perspective, Snow, Rochford, Worden \& Benford, 1986) da ação coletiva e dos movimentos sociais. Os processos de enquadramento, como esclarecem Benford e Hunt (2001: 163), "dão conta da maneira como os atores usam esquemas interpretativos para dar sentido aos seus mundos sociais e para agir em conformidade". As operações de enquadramento tornam-se explicitas, sobretudo, nas situações problemáticas, em que os atores são impelidos a propor interpretações das situações e a atribuir causas, responsabilidades, soluções, etc. (Cefaï, 2001: 60) e fazem-no segundo repertórios culturais e as gramáticas da vida pública.

Ora, justamente, o caráter público e cénico da vida social é encarado por $\operatorname{Goffman}(1973,1974)$ em termos de percepção mútua, de copresença, de encenação ritualizada e daquilo que o autor designa por "ordem expressiva". A ação coletiva requer convenções, regras, rituais e cooperação, com ajustamentos recíprocos, e a situação da ação comporta um aspecto dramatúrgico (a cena ${ }^{6}$, o drama, os atores, a designação dos protagonistas, os meios retóricos utilizados pelos atores, etc.). Ou seja, Goffman entende que as ações e o desempenho dos atores são mediados pelas convenções e pela encenação em curso. Nessa medida, a ação coletiva é regulada pela gramática da vida pública e encontra-se sob o regime de convenções implícitas (Goffman, 1974; Cefai e Lafaye, 2001).

Numa aproximação ao objeto de estudo aqui colocado (a manifestação do 15 de setembro), pode invocar-se, como exemplo, o desfile de uma manifestação com encadeamentos sequenciais de movimentos, palavras e gestos, com convenções, significações, repertórios e rituais partilhados pelos participantes, havendo uma regulação da ação conjunta pela dimensão cénica. A ação (individual e coletiva) situa-se numa situação social que pode ser entendida como uma cena pública onde há uma distribuição de papéis, controlo recíproco em situação de copresença e definição da situação. Deste modo, a ação liga-se à situação na qual decorre e é no quadro desta que se dota

6. A noção de cena remete para as noções de ator, desempenho e ação, numa acepção dramatúrgica, e para a dimensão de visibilidade. 
de uma retórica que convoca as convenções coletivas e as gramáticas da vida pública. Ao mesmo tempo, a retórica e as convenções usadas organizam a situação.

\section{Ação coletiva e situação}

Colocada a ação coletiva nos termos da ação situada, importa, a par da mediação pelas convenções e pela dimensão cénica, encarar a situação. A fenomenologia social (Berger e Luckmann, 1985; Schütz, 1987) incluiu, no processo da definição da situação, os "constrangimentos objectivos" (Schütz, 1987), o tema (em função dos objetivos e dos interesses do agente) e a seleção de elementos de conhecimento comum "pertinentes". O tratamento da situação e da sua interpretação é tão importante quanto, nesse sentido, "agir é tratar uma situação" (Fornel e Quéré, 1999: 11).

Ora, a corrente interacionista (H. Blumer, 1969) e a perspetiva construtivista (Berger e Luckmann, 1985) salientaram, precisamente, como as significações compõem a realidade ${ }^{7}$, entendendo que as situações são o que são em função do modo como são definidas, sendo a definição uma questão de interpretação. Blumer (1969) havia já sublinhado que a ação conjunta supõe interpretações e ajustamentos recíprocos de comportamentos no quadro de uma situação.

Fornel e Quéré (1999:10) comentam, a propósito da perspetiva que prevaleceu nas ciências sociais reclamando-se ou não da Escola de Chicago, que "as situações são aquilo a que os sujeitos se ajustam via as definições que eles próprios dão. Estas definições são necessárias para que uma decisão seja possível". Mas, como os autores salientam, é preciso também ter em conta que as situações permanecem frequentemente indeterminadas, sem que esta indeterminação seja um problema de um ponto de vista prático. Esta perspetiva é defendida pela etnometodologia que, embora herdeira da fenomenologia social de Schütz, inaugurou uma outra concepção da ação situada, rompendo com os modelos da ação racional.

Com efeito, os atores não têm de se ocupar explicitamente com a definição da situação, podendo esta ocorrer caso se mostre necessário, ou estar implícita a partir daquilo que é dito e daquilo que é feito e sem que se preste atenção, seen but unnoticed, como diria Garfinkel. Os atores, na sua vida quotidiana, realizam ações conjuntas concertadas, entendem-se sobre as definições comuns das suas situações de ação, colocam-se de acordo sobre aquilo que fazem e vêem, cooperam uns com os outros em ações recíprocas e interagem conjuntamente, etc., como defendeu Garfinkel (1984), graças a uma compreensão comum e à ordem social e moral. Esta ordem é gerada nas atividades práticas situadas e nas experiências da vida em conjunto. Assim sendo, a perspetiva é que as situações sociais decorrem das interações, ao mesmo tempo que se vão revelando em função do curso da ação, das circunstâncias, das contingências e das próprias consequências daquilo que é dito e que é feito. Ligam-se, portanto, aos discursos e atividades que nelas são produzidos e são compreendidas pelo uso da linguagem natural. Há, assim, uma elaboração recíproca entre a ação, a linguagem que a acompanha, e a situação, e uma indexicalidade (ou indicialidade) e reflexividade entre a ação e a situação.

Deste modo, se uma ação coletiva ou uma mobilização pública requer a partilha de interesses e a definição ou a compreensão comum da situação, também é verdade que a ação se ajusta à

7. "Os humanos comportam-se perante as coisas mediante as significações que estas têm para eles" (Blumer, 1969:2; apud Fornel e Quéré, 1999:10). 
situação, ao mesmo tempo que a organiza. Como observei numa análise sobre os públicos (I. Babo, 2015: 68), "todo o público se liga à situação que o gera enquanto público. O público emerge numa situação de recepção e liga-se a essa mesma atividade", "não pré-existe à situação que o origina". Logo, o desenrolar de uma ação conjunta em situação depende do acordo sobre as atividades, as suas significações e consequências, e sobre as dinâmicas de encenação e de cooperação entre atores, e pode transformar uma situação indeterminada numa situação determinada.

A questão que pretendo colocar, de seguida, é se o carácter coletivo da ação coincide com a dimensão pública desta.

\section{Ação pública, ação coletiva e emoção}

A ação coletiva, como os públicos em Dewey, tem grande probabilidade de se desencadear perante problemas cujas consequências indiretas afetam um grupo ou comunidade e aos quais se reage. Em The Public and its Problems (1927), Dewey, ao mesmo tempo que defende a importância da conversação, da cooperação, da experiência partilhada, considera que o público, na verdadeira acepção da palavra, se constitui em resposta a um problema. A constituição do público, em Dewey, logra em resultar da "lógica da investigação" 8 e do "trabalho da experimentação". Dewey (2010 a: 277) argumentava que somente uma investigação (inquiry) contínua, persistente e conectada com as condições de uma situação, permite a formação de uma opinião sobre os assuntos públicos ${ }^{9}$.

A sociologia dos problemas públicos (Gusfield, 1981; Jasper, 1997; Cefaï, 1996) adopta a perspetiva construtivista da construção dos problemas, reportando-se a uma atividade coletiva que, como assinalam Trom e Zimmermann (2001: 282), é "complexa, comprometendo uma série de atores heterogéneos e ancorada em contextos particulares".

Para Gusfield (1981), a ação coletiva também constitui um modo de definir, tratar, modificar ou resolver problemas, por parte de atores coletivos, instituições ou movimentos sociais, desenvolvendo-se, frequentemente, em resposta a situações problemáticas (ações de resposta a situações tais como o abuso do álcool e a condução automobilística, a insegurança urbana, o terrorismo, as más condições de vida, etc.). Uma vez constituído um problema público ou uma situação problemática, identificadas as causas do problema, as responsabilidades e a quem compete intervir e resolver a situação problemática, a ação coletiva (pública), que fixa sobre si a atenção de um público, desencadeia-se em resposta, reclamando das instituições, associações ou dos poderes públicos competentes o dever da sua resolução. Nesses casos, como sustenta Gusfield (1981), a ação coletiva adquire o estatuto de ação pública, constituindo a ação pública uma sua modalidade, ou

8. Assim como a experiência e a individualização, em Dewey, implicam a transformação correlativa do objeto e do sujeito, das condições da ação, dos interesses, das circunstâncias de uma vida e da individualidade que advém dessas transações, também a investigação como a participação - política, ética, jurídica, económica, etc. - é da ordem do poder dos indivíduos sobre as condições que os afetam.

9. "Uma investigação sistemática e contínua sobre todas as condições que afectam a associação, assim como a disseminação pela imprensa, são uma condição prévia para a criação de um público” (Dewey, 2010 a: 322). 
seja, uma ação colectiva que visa tratar problemas públicos e que se desenrola nas cenas e arenas públicas ${ }^{10}$.

Destacam-se, assim, dois aspetos das ações públicas: um primeiro que consiste numa dimensão dramatúrgica, em termos de ritualização numa cena pública e perante um público e em termos da sua formulação e retórica utilizada (por exemplo, a ação que constitui uma denúncia pública contra isto ou aquilo e que usa essa linguagem: "Contra a austeridade. Que se lixe a Troika. Queremos as nossas vidas" - slogan utilizado na mobilização do 15 de setembro de 2012, em Portugal); um segundo aspeto prende-se com tratarem-se de ações recebidas e julgadas por um público, ou de ações de movimentos sociais e de opinião que apelam à opinião pública e a mobilizam, constituindo uma reação e um modo de tratar e modificar as situações problemáticas. Logo, é "pública" a ação coletiva que tem lugar numa cena pública, que é dramatizada, ou comporta uma dimensão dramatúrgica ligada ao drama, problema ou causa em curso, é recebida e julgada pelo público e retém a atenção coletiva.

Uma ação pública constitui, portanto, uma resposta a um acontecimento, tema ou problema e nela se inscrevem desde a sensibilidade moral, valores e expectativas, usos e costumes, hábitos, formas de vida, aos direitos públicos ou às normas do direito. Os sentimentos e as emoções acompanham a ação pública, ou a ação coletiva, na medida em que se, por um lado, se organizam investigações, explicações e interpretações que a sustentam, contribuindo aliás para a sua configuração, por outro lado, nela também se exprimem e simbolizam emoções. Toda a experiência pode ser emotiva, cognitiva, normativa e/ou prática. Como explanou Dewey (2010 b), a experiência acontece entre um indivíduo e objetos, ou entre este e outras pessoas, e resulta de relações intersubjetivas, da comunicação, da exposição aos objetos, aos acontecimentos e às condições do meio ambiente que afetam o indivíduo. A experiência ajusta-se às condições do meio ambiente e à situação, que é composta pela interação entre as condições objetivas e as condições internas, não sendo em si mesma nem puramente física nem mental ${ }^{11}$. É assim que na experiência existem, em graus diversos, afeção, ação, emoção, entendimento e cognição, sendo as emoções que conferem unidade à experiência ${ }^{12}$.

Ora, os atores cooperam, ou concorrem, na defesa dos seus interesses e direitos, ao mesmo tempo que definem os problemas, ou as causas, avançam explicações e interpretações, mas também expressam emoções. A participação das emoções na ação coletiva, nas tomadas de posição e de ação dos coletivos, tem sido defendida por vários autores (P. Livet, 2002; P. Paperman e R. Ogien,

10. O álcool e a condução rodoviária (problema analisado por Gusfield; 1981), por exemplo, são problemas sociais que em dado momento se tornaram em problemas públicos; mas, para que uma tal transformação tenha tido lugar, foi necessário que uma situação problemática tenha focado sobre si a atenção coletiva, tenha constituído assunto de discussão nas arenas públicas e tenha sido objeto de uma ação pública.

11. «Chaque expérience est constituée par l'interaction entre «sujet» et «objet», entre un soi et son monde, elle n'est en elle-même ni simplement physique ni simplement mentale» (Dewey, 2010 b: 403).

12. Neste caso, a experiência forma um todo, é singular, comporta o seu começo e o seu fim, destaca-se do que a precede e a sucede e possui características que a individualizam, tendo um valor intrínseco. "Acontece muitas vezes, contudo, que a experiência vivida seja rudimentar. Há coisas de que fazemos uma experiência, mas não de maneira a compor uma experiência. (...) Diversamente deste tipo de experiência, vivemos uma experiência quando a matéria que constitui objeto da experiência vai até ao fim da sua realização. (...) Uma tal experiência forma um todo; possui em si características que a individualizam e basta-se a si mesma. Trata-se de uma experiência” (Dewey, 2010 b: 80-81). 
1995; Thévenot, 1994, 1997; L. Quéré, 2003, D. Cefaï, 2007, 2009; etc). Quéré (2015) considera que os afetos estão particularmente envolvidos na percepção individualizada de eventos, objetos e situações e que "a dinâmica de uma ação coletiva, e a da identidade coletiva que a apoia, são em grande parte emocionais".

"A emoção coletiva é tanto mais forte quanto os que nela participam se pensam e se vivem eles próprios como membros do coletivo em causa e afetado por essas consequências: 'Numa emoção coletiva, as expectativas, os fins e as preferências são também eles assumidos como coletivos e as expressões da assembleia estão aí para confirmar que, já que as emoções são partilhadas, as expectativas, fins e preferências também o são. A partilha da emoção é, muitas vezes, a única maneira de compreender a convergência dos fins e das preferências' (Livet, 2002, p. 125). Quanto maior for a certeza de que o objeto da emoção é o mesmo para todos, ou quanto mais a convicção sobre a convergência dos objetivos for forte, mais esta certeza é ela própria um fator de emoção" (Quéré, 2015: 20-21).

A ação coletiva não está somente, ou sobretudo, munida de interesses ou fins comuns, mas supõe a partilha de emoções e uma experiência conjunta que é padecida e ressentida. Nessa medida, toda a mobilização coletiva ou ação pública incorpora o modo como um problema, assunto, causa, ou situação, foi sentido e avaliado por uma comunidade de sentimento, de emoção e de ação. É de uma outra concepção de ação coletiva que se trata, quando, a par dos interesses, vontade comum e cognições, se encara como as emoções ou os sentimentos integram a ação e a experiência. Segundo Dewey, os sentimentos dão unidade à experiência. Cefaï (2009) elucida isso mesmo,

"Mais radicalmente, não se trata simplesmente de reabilitar um "objeto" até então negligenciado pela pesquisa ou pela análise, mas de transformar a definição da ação coletiva. A afetividade não é um tema entre outros. Ela é o que faz com que haja experiência, tanto perceptiva quanto cognitiva ou moral. Não é uma coloração de estados de fato ou de estados de consciência. Ela é o que garante nosso contato com os outros e com as coisas, e o que mantém unidas as situações nos situando nelas. A ação coletiva não está toda no agir, mas também no sofrer e no compartilhar. Ela tem uma dimensão de afeição e paixão coletiva. Mais do que serem propulsados em direção a um ponto estratégico, os membros que se engajam são afetados por situações que contribuem para definir e dominar" (Cefaï, 2009: 31).

Sabendo-se que uma ação partilhada na internet não constitui em si mesma uma ação coletiva, a interrogação que coloco, de seguida, é a seguinte: pode a ação partilhada nas redes digitais sociais vir a constituir uma ação coletiva?

\section{Ação coletiva e ação conectada}

A ação partilhada com base nas interações sociais e na atividade comunicativa é uma ação social que detém convenções implícitas, emoções, cognições e sentidos que interlocutores e atores conferem às consequências do que dizem e fazem. Nas redes sociais, ou nas ligações electrónicas, partilham-se gostos, opiniões, sentimentos, interesses (pessoais e coletivos), crenças, expectativas, e há simulação de proximidade. Assim, na medida em que utilizadores-emissores-receptores colocam em comum informações, gostos, interesses, etc., e atribuem significações ao que transmitem, 
exibem e partilham, existe ação partilhada. Mas dir-se-á que a ação coletiva requer um maior nível de participação e cooperação.

A ação coletiva, como vimos, está ligada ao caráter coletivo de uma ação desenvolvida por atores coletivos, que são os sujeitos dessas ações (a ação dos grevistas, dos movimentos de opinião, dos intelectuais, dos adeptos de clubes desportivos, das comissões de cidadãos, das associações, dos sindicatos, dos movimentos sociais, etc.). Constitui-se como ação conjunta e concertada, em maior ou menor grau, em torno de sentimentos, interesses, fins ou vontade comuns e incorpora uma atenção conjunta. Esta última deve estar orientada para os mesmos objetos ou assuntos, ou movida por interesses e sentimentos comuns. Como na análise dos públicos em Dewey (2010 a), a constituição do público depende da comunicação, da discussão, dos interesses e emoções comuns, mas também da consciência de si, enquanto público. O que confere o sentimento de pertença a um coletivo ou a um público é, precisamente, ele tomar consciência de si. É indispensável o sentimento de fazer parte desse coletivo ou público, assim como o conhecimento das condições que o originaram. A consciência do coletivo, que o indivíduo integra, favorece a adesão a interesses, cognições, sentimentos, emoções e ações comuns, ao mesmo tempo que pode também o indivíduo encontrar-se a si mesmo, mediante um processo de socialização e individuação.

A atenção conjunta requer convergência, partilha e associação, o que cria, como entende L. Quéré (2015), um "espaço comum", que é sempre um lugar de sociação e de individuação. Quéré (2015) recolhe de Charles Taylor (2004) a distinção entre dois tipos de focalização e entre dois tipos de espaço comum: "espaço comum tópico" e espaço comum não local "metatópico". A atenção conjunta implica que os parceiros prestem mutuamente atenção a um objeto ou a um acontecimento, partilhando também a experiência da focalização comum e da atenção recíproca nesta focalização comum. Como elucida Quéré (2015: 17), ela "caracteriza-se, então, não só por uma 'manifestação mútua' da focalização comum, mas também por uma 'manifestação mútua' da atenção recíproca nesta focalização comum". Como no caso da conversa ou, de acordo com o exemplo dado por Taylor, a partir de uma assembleia reunida num determinado lugar, surge um espaço comum tópico, que se distingue da criação de um espaço metatópico, "caso em que cada uma delas [pessoas que nunca se encontraram] dá conta de se interessar, por si própria, à mesma coisa" (Taylor, 2004: 85-86, apud Quéré 2015: 16) ${ }^{13}$.

Nas redes electrónicas, partilham-se interesses, preferências, emoções, sentimentos e cognições e a atenção partilhada (e não propiamente conjunta) está sujeita a um princípio de dispersão, fragmentação e efemeridade ${ }^{14}$. O que resulta das ligações nas redes são relações desespacializadas e destemporalizadas, ou relações atópicas que não estabelecem um espaço comum metatópico, como lugar do público e da opinião pública. A comunicação electrónica que se processa no quadro de um ecossistema reticular, na terminologia de Massimo Di Felice (2012, 2013), constituído por

13. Um espaço metatópico, instituído com a esfera pública, tal como foi teorizada por Habermas (1962), "É um tipo de espaço comum (...) no qual pessoas que nunca se encontraram se apreendem a si próprias como estando comprometidas numa discussão e capazes de alcançar uma mesma opinião" (Taylor, 2004: 85-86, apud Quéré 2015: 16).

14. Embora não deixe de ser importante lembrar que a efemeridade da comunicação digital é, ao mesmo tempo, perpetuidade, na própria medida em que tudo o que lá se passa está sujeito à reprodutibilidade técnica e ao arquivo. Nas redes digitais, o arquivo de mensagens, imagens e vídeos é ilimitado. 
dados, algoritmos, mediações e ligações, cria uma condição de habitar "atópica", como o autor sustenta, nos meios ecossistémicos, relacionais e conectados dos contextos reticulares.

Nas redes, será, então, mais adequado falar-se em ação conectada. Bennett e Segerberg (2012) colocam a existência de duas lógicas distintas de ação: a ação coletiva e a ação conectada (connective action). O modelo alternativo emergente, a que os autores chamam lógica da ação conectada, aplica-se às situações hoje correntes em que os laços dos grupos estão a ser substituídos pela larga escala dos fluxos das redes sociais (Castells, 2002) e as organizações formais (sindicato, partido, igreja, etc.) perderam capacidade de mobilização dos coletivos. Bennett e Segerberg defendem que a ação nas redes digitais tem a sua lógica e dinâmica próprias - a ação conectada implica uma lógica própria - por isso não deve conformar-se aos sistemas clássicos da ação colectiva e dos movimentos sociais ${ }^{15}$.

Enquanto a ação coletiva e a ação pública, como vimos, são ações conjuntas que se desenrolam nos lugares públicos de acordo com interesses comuns e em resposta a problemas, instituindo espaços comuns de protesto, nas praças e ruas, como lugares de partilha, manifestação e expressão públicas, com uma dimensão cénica de copresença física, as ações conectadas nas redes resultam do uso de processos tecnológicos (sem, com isto, arrogar-se um determinismo tecnológico) e são mais individualizadas. Nas tecnologias de comunicação pessoais electrónicas, a partilha de tweets, textos, imagens, sons, em vários formatos - áudio, vídeo, imagens, etc. - em plataformas colaborativas, envolve o colocar em comum ou a comunicação pública de interesses, preferências, emoções, expectativas, valores, preocupações, causas ou protestos e, simultaneamente, a personalização dos gostos. Como Bennett e Segerberg (2012) notam, um problema tornado comum pode ser sentido de diferentes maneiras e sustentado por diferentes razões.

Aqueles que têm acesso a dispositivos tecnológicos pessoais, e que estão familiarizados com as práticas das redes sociais, buscam caminhos mais personalizados para uma ação concertada, na medida em que se ajustam a uma lógica diferente de organização, que é a lógica da rede e da ação conectada. Isto convida a encarar a rede como uma estrutura organizacional em si (Bennett e Segerberg, 2012: 753), na própria medida em que as tecnologias da comunicação e os media digitais acabam por também atuar como agentes de organização. Como Bennett e Segerberg (2012) examinaram, a (auto)organização de mobilizações e de protestos, como o Movimiento 15-M ou Indignados ou Occupy Wall Street, cria uma ação conectada com mediação digital, cujos atos de partilha se estendem à convocatória das ações e que podem desembocar em ação colectiva situada ou em ação coletiva no espaço público.

“Tanto os atos de compartilhar esses apelos pessoais para a ação, como as tecnologias sociais através das quais eles se transmitem, ajudam a explicar quer como os acontecimentos são comunicados às audiências externas quer como a própria ação é organizada. Com efeito, no limite, a rede de comunicação torna-se a forma de organização da ação política (Earl \& Kimport, 2011)" (Bennett e Segerberg, 2012: 745).

Esta distinção que os autores estabelecem significa que não se trata de estender a lógica da ação coletiva à larga escala da rede ou, o inverso, desdobrar a ação conectada fazendo-a apossar-se da

15. "Sugerimos que a lógica da ação conectada implica uma dinâmica própria e, portanto, merece uma análise nos seus próprios termos analíticos" (Bennett e Segerberg, 2012: 748). 
ação coletiva. Os Indignados, ou os instigadores da manifestação Que se Lixe a Troika (Portugal, 2012), alcançaram níveis elevados de comunicação em rede, com múltiplos utilizadores, através de imagens e mensagens espalhadas de modo viral nas redes sociais. As ações mediadas digitalmente e as ações coletivas, estas últimas sobretudo quando formadas em torno de uma organização, como nos caso dos movimentos sociais convencionais, apresentam diferenças nas lógicas subjacentes e no papel da comunicação como um princípio organizador. Por isso, a ação conectada requer um outro tipo de análise, na medida em que não se lhe aplicam muitas das características e quadros das ações coletivas e dos movimentos sociais.

Nas redes, trata-se de passar a palavra e de mobilizar adesões pessoais, dirigindo-se a audiências externas, como Bennett e Segerberg analisam a propósito dos protestos Put People First (Londres PPF, 2009) e dos Indignados, usando tecnologias digitais comuns, com grande sucesso na comunicação de mensagens políticas simples diretamente no Facebook ou no Twitter. Os autores deram conta que os próprios processos de comunicação representavam formas importantes de organização.

"Estas redes podem operar de forma importante através dos processos organizacionais dos média sociais e a sua lógica não exige um forte controle organizacional ou a construção simbólica de um "nós" unido. Nós sugerimos que a lógica da ação conectada implica uma dinâmica própria e merece, portanto, uma análise nos seus próprios termos analíticos" (Bennett e Segerberg, 2012: 748).

Um primeiro passo na compreensão da ação digital em rede (digital networks action / DNA), consideram os autores, consiste em definir a comunicação personalizada e o seu papel, juntamente com o papel dos média digitais, na organização da ação conectada. Isto na medida em que diversas desagregações nas associações de grupos e de instituições têm vindo a acentuar a fragmentação estrutural e a individualização nas sociedades contemporâneas. Seguem-se orientações individualizadas que resultam numa ligação à política "como expressão de esperanças pessoais, estilos de vida e protestos", em que falha uma "identificação comum de grupo ou ideológica" (Bennett e Segerberg, 2012: 744), constituindo estes aspetos, segundo os autores, um pano de fundo importante para esta análise.

Enquanto a ação coletiva e os movimentos sociais convencionais exigem escolhas e compromissos por parte dos atores e a adopção de um "nós", ou de identidades sociais ou coletivas, a ação digital em rede (DNA), baseando-se em quadros de ação pessoais, organizados em torno de tecnologias sociais, não requer esses compromissos.

"As redes de ação conectada são tipicamente conjuntos de processos muito mais individualizados e tecnologicamente organizados que resultam em ação sem a exigência de um enquadramento de identidade coletiva ou de recursos organizacionais necessários para responder efetivamente às oportunidades" (Bennett e Segerberg, 2012: 750).

Bennett e Segerberg (2012) estabelecem uma tipologia que se refere ao surgimento de duas formas de ação conectada na rede digital e de uma forma de ação coletiva, presente nos movimentos sociais e que utiliza as redes digitais para aspectos importantes da sua organização ${ }^{16}$. Os

16. "The typology is intended as a broad generalization to help understand different dynamics. None of the types are exhaustive social movement models. Thus, this is not an attempt to capture, much less resolve, the many differences 
três tipos considerados são os seguintes: connective action self organizing networks, connective action organizationally enabled networks, collective action organizationally brokered networks (ação conectada auto-organizada nas redes, ação conectada estimulada organizacionalmente nas redes, ação coletiva organizacionalmente mediada nas redes). No caso da ação coletiva conduzida por organizações (fora ou dentro da rede), um traço determinante é o seu carácter de organização e coordenação. Por sua vez, a ação conectada apresenta um carácter mais pessoal e individualizado, sendo a expressão pessoal partilhada de modo mais acentuado no primeiro tipo, ou seja, na connective action self organizing networks, evitando o envolvimento de organizações formais, enquanto no tipo da ação conectada em rede estimulada organizacionalmente (connective action organizationally enabled networks), surgem nas redes, muitas vezes, organizações que, em segundo plano, se encontram vagamente vinculadas às dinâmicas comunicacionais.

Earl \& Kimport, em Digitally enabled social change (2011), mostram como existem diversos novos modos de usar a internet para participar e apoiar protestos, desde os "e-movimentos" (online), às "e-táticas" (e-tactics) e às "e-mobilizações". Estas últimas têm ajudado "a tornar a quantidade de manifestantes [off-line] existentes maior, mais coordenada e mais fácil de mobilizar rapidamente" (Earl, 2017: 54). Pode, como consideram Earl \& Kimport (2011), a rede de comunicação tornar-se a forma organizacional da ação política, revelando novas formas de ação com repercussões teóricas e impactos nos movimentos sociais convencionais (impactos limitados, impactos de mudança de escala e impactos de mudança de modelo), tendendo a ocorrer mudança de modelo nos casos de e-táticas e e-movimentos, enquanto os casos de e-mobilizações se mantêm com mudanças de escala ou mesmo sem mudanças. Nos casos de "e-táticas" e "e-movimentos", como explicam Earl \& Kimport (2011) e Earl (2017), as mudanças ao nível do movimento social convencional são efetivas. Ou seja, as mudanças operadas nas formas de participação, de mobilização e, sobretudo, "de organizar sem organizações", "apontam para o desenvolvimento de um novo repertório digital de controvérsias claramente diferente de repertórios anteriores" (Earl, 2017: 62).

Earl (2017) estabelece diferentes tipos de ativismo na internet e reporta-se ao estabelecido por Earl \& Kimport (2011: 61),

"esses usos alavancados da internet estão levando à criação de um 'repertório digital de controvérsia', em que o ativismo é mais efémero e episódico e também mais facilmente realizado sem copresença. Eles mostram que esse repertório inclui táticas clássicas do movimento social utilizadas para uma ampla variedade de fins, algumas das quais dirigidas a clássicos objectivos do movimento social (por exemplo, acabar com o racismo), ao passo que outras são bastante incomuns e, por vezes, aparentemente, até não orientadas politicamente (por exemplo, protestar contra um projeto de produto por uma empresa)".

É assim que o campo das mobilizações públicas e dos novos movimentos de protesto (Cefaï, 2005, 2007) - que se têm desencadeado com maior ou menor organização, com maior ou me-

among those who study social movements. We simply want to highlight the rise of two forms of digitally networked connective action that differ from some common assumptions about collective action in social movements, and, in particular, that rely on mediated networks for substantial aspects of their organization" (Bennett e Segerberg, 2012: 755). 
nor utilização das redes, com permanência no tempo ou efemeridade - requer ser analisado na variedade das suas ocorrências.

\section{AÇão COLETIVA E AÇÃo CONECTADA. O ATIVISMO EM REDE E NA RUA}

\section{A manifestação do 15 de setembro em Portugal}

Se, à partida, poderia julgar-se que as duas lógicas da ação coletiva e da ação conectada corresponderiam à ação organizada fora da rede, por um lado, e à ação suportada pelas ligações tecnológicas, por outro, ou seja, que na rede se trataria de ação conectada e na rua de ação coletiva, aquilo que se dá a analisar nas mobilizações online, seguidas de fenómenos de rua, é a ocorrência destas duas formas de ação nas redes e, frequentemente, uma fronteira ténue entre as duas. Aliás, como Bennett e Segerberg (2012) consideraram, deparamo-nos com ações coletivas que são mediadas e negociadas nas redes (collective action organizationally brokered networks).

No quadro das mobilizações convocadas nas redes ("e-mobilizações"), poderão ações quasecoletivas (e quase-coletivos) ${ }^{17}$ formar-se online, ou não se formar. Tratando-se de protestos convocados online por organizações, a ação coletiva e o coletivo existem, podendo, no entanto, não se manter online. A interrogação que aqui coloco prende-se, especificamente, com a possibilidade ou a impossibilidade da ação coletiva na rede, no quadro das e-mobilizações que derramaram para a rua. Ora, é importante considerar que o estudo das mobilizações públicas que se iniciaram ou mantiveram online e desembocaram na rua requer uma análise caso a caso. Com os protestos e as mobilizações a ocorrerem tanto online como offline, com ações coletivas que, uma vez lançadas na rede, se dispersam e individualizam, ou com ações conectadas que podem vir a adquirir uma certa configuração de ação quase-coletiva, tendem a instaurar-se regimes híbridos, constituídos por comunicações online e offline, ações conectadas e ações coletivas, ações individuais e quasecoletivas. Vários autores referem ecologias de ação complexas (Chesters \& Welsh, 2006), hibridez de vários tipos (Chadwick, 2011) e mudanças que advêm das formas de uso das tecnologias (Earl \& Kimport 2011):
"O debate sobre novas formas de ação coletiva pode refletir ecologias de ação cada vez mais complexas (Chesters \& Welsh 2006). Múltiplas formas organizacionais que operam em tais ecologias podem ser difíceis de categorizar, não somente porque podem se transformar ao longo do tempo ou contexto, revelando hibridez de vários tipos (Chadwick 2011). Além disso, o trabalho de protesto e organização está ocorrendo tanto on-line como fora, usando tecnologias de diferentes capacidades, às vezes tornando a distinção online / offline relevante, mas geralmente não" (Earl \& Kimport 2011; Bimber et al., imprensa)" (Bennett e Segerberg, 2012: 748-749).

17. Inspiro-me em Dayan ("Télévision, le presque-public”; 2000) que fala em quase-públicos. Na sua análise dos públicos televisivos, Dayan (2000) refere-se a "quase-públicos", por não apresentarem as características dos públicos: os públicos da televisão podem ser tomados como "quase-públicos", no sentido em que estão dispersos, inorganizados e numa relação de maior passibilidade ao objeto. Do mesmo modo, neste texto, uso a expressão de ação "quase-coletiva" dada a dispersão, menor organização, ou ausência desta, maior nível de reação ou reatividade do que atividade conjunta. 
Também Castells (2012) se reporta a um "espaço público híbrido", na medida em que o ciberespaço se conecta com o espaço urbano, constituindo-se tecnológica e culturalmente pela ocupação deste último e pelas ações nas redes sociais, com comunidades instantâneas e novas formas de mobilização e organização.

No caso do movimento QSLT ("Que se lixe a Troika. Queremos as nossas vidas"), como Babo e Silva $(2015,2016)$ analisaram, o mesmo emergiu nas redes electrónicas e confluiu para as ruas, nas manifestações do dia 15 de Setembro de 2012, em várias cidades, com carácter de um novo movimento de protesto, por relação ao movimento social tradicional, regularmente convocado e liderado por organizações (partido político, sindicato, associações, etc.). A convocatória para a manifestação do 15 de setembro, dia em que a apresentação do primeiro pacote de medidas de austeridade por parte do governo estava iminente, num contexto de grandes dificuldades socioeconómicas e insatisfação generalizada, surgiu nas redes sociais digitais a partir da iniciativa de cidadãos que, em protesto contra as políticas governamentais, incitaram à mobilização em Lisboa, que acabou por se estender a outras cidades.

Nesta mobilização ou movimento de protesto, identifica-se, antecedendo-a, a formação de uma ação conjunta conduzida por um grupo de cidadãos descontentes com a situação de crise que o país atravessava e com as políticas fixadas. Estes ativistas partilham indignações, emoções, interesses e objetivos comuns, pretendendo mobilizar outros ativistas anónimos e promover uma grande manifestação nacional, numa demonstração de cidadania democrática e rejeição da austeridade. É, com efeito, de uma ação coletiva que se trata, que se expande mediante a ação digital em rede.

O grupo dos vinte e nove subscritores, que cria a plataforma "Que se lixe a Troika-Queremos as nossas vidas" (QSLT), apresenta-se na internet ou publicamente como não filiados em partidos políticos ou outras organizações, embora a ideia original para o movimento tenha procedido da organização "Precários Inflexíveis" (PI), tendo, contudo, sido fora dos PI que a iniciativa se desenvolveu. A ação coletiva emerge e dissemina-se nas redes sociais como um movimento de cidadãos comuns, apartidário, horizontal, espontâneo e sem organizações formais. Trata-se de uma ação coletiva que origina e suporta o movimento QSLT e não requer, como sua condição, a ligação a uma organização formal. Portanto, o movimento QSLT constitui uma ação coletiva desencadeada por um grupo de atores que partilha interesses, motivações e objetivos comuns e propaga-se e expande-se pela ação digital em rede. Nessa medida, há uma amálgama entre a ação coletiva e a ação conectada, sendo que, na rede, se multiplicam e diversificam as ligações e opiniões e coexistem tomadas de posição e emoções coletivas e individualizadas. Há, por um lado, a lógica da ação coletiva do grupo que se forma e que difunde a sua opinião (pública) e apelo à mobilização na internet. Por outro lado, a ação desencadeada na rede torna-se comunicação reticular de todos para todos ou de todos com todos (é o modelo de comunicação many to many, que Castells [2009] refere, em oposição ao modelo one to many dos média tradicionais) e facilmente se desvincula de protagonistas e promotores (ou, eventualmente, de lideranças, caso existam). Assim, dispersase como connective action organizationally enabled networks (Bennett e Segerberg, 2012), i.e. ação conectada que é ativada na rede por uma organização. Ou seja, enquanto ação conectada ativada pelo grupo ou o coletivo que concebeu a plataforma, publicou o manifesto e desencadeou a comunicação na rede e o movimento. Como constava no texto da convocatória, disponível no facebook, 
"Este é um apelo de um grupo de cidadãos e cidadãs de várias áreas de intervenção e quadrantes políticos. Dirigimo-nos a todas as pessoas, colectivos, movimentos, associações, organizações não-governamentais, sindicatos, organizações políticas e partidárias, que concordem com as bases deste apelo para que se juntem na rua no dia 15 de Setembro".

Uma vez na rede, o manifesto subscrito pelo grupo vigora tanto quanto a comunicação se dissemina de modo disperso, individualizado, apartidário ou sem organização partidária na sua origem (embora participem indivíduos provenientes de organizações, já que elementos dos PI e do partido Bloco de Esquerda se juntaram nos encontros do grupo e acabaram por desempenhar alguma coordenação). Personalidades, anónimos, organizações, associações propalaram a sua adesão, resultando na grandiosa manifestação do dia 15 de setembro de 2012, que constituiu um movimento de protesto alargado, heterogéneo, muito participado e concorrido, e com uma dimensão acontecimental que o diferencia do movimento social tradicional. A forma de comunicação interveio como modalidade de configuração e de organização ${ }^{18}$. O "apelo" online, a partir da própria lógica da rede, constituiu uma modalidade de comunicação, mas também de organização ${ }^{19}$, mediante processos mais individualizados, do que a tradicional convocatória unidirecional ${ }^{20}$, e tecnologicamente organizados.

O 15 de setembro consistiu numa mobilização pública que ocupou a rua, sem organizações sociais estruturadas (sindicato, partido, associação) a convocar, comandar ou a encabeçar as manifestações. Durante o tempo da sua duração, constituiu-se como ação coletiva (ou ações coletivas), com cerca de um milhão de portugueses nas ruas das cidades a manifestar-se. A dinâmica de mobilização na rede, ou da ação conectada, contou com uma elevada adesão de "ativistas cibernéticos" (muitos dos quais poderão não se ter manifestado na rua), em razão do descomprometimento e de diferentes graus de envolvimento. Outros saíram para a rua e incorporaram as manifestações sem, necessariamente, terem previamente tomado posição online. Mas o modo como as manifestações proliferaram em várias cidades e como uma tal diversidade, pluralidade e heterogeneidade (etária, social, política, cultural) de cidadãos se reuniram nas ruas, adveio como consequência, em grande parte, da comunicação conectada que acaba por funcionar como modalidade de organização. A ação conectada foi responsável pela tão numerosa, diversa e plural mobilização pública de atores. O que juntou aqueles que se manifestaram na rua foram sentimentos, emoções, ideias, convicções, crenças e ações contra a austeridade.

18. "In this interactive process of personalization and sharing, communication networks may become scaled up and stabilized through the digital technologies people use to share ideas and relationships with others. These technologies and their use patterns often remain in place as organizational mechanisms. In the PPF and the indignados protests, the communication processes themselves represented important forms of organization" (Bennett e Segerberg, 2012: 746).

19. A ação conectada introduz a sua lógica de comunicação como um princípio organizador (Bennett e Segerberg, 2012).

20. A convocatória tradicional segue o modelo da comunicação de massa. Por seu lado, a comunicação reticular não tem direção. Como referi anteriormente (I. Babo, 2017: 95), "com a rede sai-se, definitivamente, do esquema linear e unidirecional da comunicação, que se aplicou ao telégrafo, ao telefone e aos média tradicionais (imprensa, rádio, televisão) centrados num polo produtor que, de acordo com o modelo de irradiação da informação para audiências massificadas, não dá lugar a retorno ou retroação. Ora, a rede, como é composta pelo cruzamento de linhas mediante interconexões múltiplas, liga ao mesmo tempo várias entradas ou pontos (que podem ser indivíduos, nós de relações, sites, arquivos, etc.), havendo interação, interdependência, retroação e reversibilidade”. 


\section{5 de setembro: a luta contra a austeridade}

São as denúncias, as reivindicações, as emoções, as expectativas e os fins que movem a luta "anti-austeridade" que caracterizam a ação coletiva. Nesta intensifica-se a dimensão emocional, na medida em que há o sentimento de que o objeto da emoção - a luta contra a austeridade - é o mesmo para todos, unindo-os. Como J. Dewey (2010 b) considera, as emoções ligam e conferem unidade à experiência, ou às ações. Ao mesmo tempo, a partilha das emoções assegura a convergência dos interesses, expectativas, fins e preferências. É este o entendimento de P. Livet e L. Quéré que, como vimos, entendem que "a partilha da emoção é, muitas vezes, a única maneira de compreender a convergência dos fins e das preferências" (Livet, 2002: 125, apud Quéré, 2015: 20). O objeto da emoção é partilhado e detém um "estatuto coletivo". Por sua vez, e em retorno, como assinala Quéré (2015: 20-21) ${ }^{21}$, a convicção sobre a convergência dos objetivos é ela própria um fator de emoção.

Em torno, justamente, do sentimento "anti-austeridade", que une cidadãos provenientes de meios sociais, culturais, políticos e etários heterogéneos, desenvolvem-se fins, objetivos, ações e reivindicações públicas. Como resultado dessa convergência, em que a partilha da emoção terá sido decisiva, o objeto da emoção torna-se comum e detém um "estatuto coletivo" "22: a luta contra a austeridade diz respeito a todos e, em torno dela, forma-se o coletivo (sujeito ou ator) que resulta das manifestações. Dotado dessa consciência de si, em luta contra a austeridade, é de um coletivo que se trata, mas irrompeu como um "nós" acontecimental e efémero. Ou seja, emergiu ao sabor do acontecimento, dotando-se de uma identidade frágil e efémera, não se podendo falar de um "sujeito contestatário unificado" (Babo e Silva, 2015: 430), mas antes de coletivos (no plural) unidos pelo sentimento comum de descontentamento e indignação ${ }^{23}$. O sentimento de pertença

21. "Para que a partilha de emoções funcione como teste e como ativador de valores comuns, o seu objeto deve ter um "estatuto coletivo" - o que é o caso quando um acontecimento ou uma atividade social são apreendidos sob o aspecto das suas consequências indiretas para a vida coletiva e, ainda mais, quando são apreendidos do ponto de vista do bem comum. (...) Quanto maior for a certeza de que o objeto da emoção é o mesmo para todos, ou quanto mais a convicção sobre a convergência dos objetivos for forte, mais esta certeza é ela própria um fator de emoção" (Quéré, 2015: 20-21).

22. "A 15 de Setembro de 2012 ocorreu uma das maiores manifestações no nosso país. Esse protesto não é apropriável por grupos de cidadãos ou partidos, pois pertence a todas as pessoas que nele participaram", segunda-feira, 15 de setembro de 2014; http://queselixeatroika15setembro.blogspot.pt/

23. Na análise do 15 de setembro, Babo e Silva (2015: 430) consideraram que não existiu um "sujeito contestatário unificado", tal como, pela própria natureza heterogénea das manifestações, surgem aspetos inovadores ou de mudança em relação aos movimentos sociais convencionais: "Este movimento insere-se na linha de outros internacionais e como tal partilha do mesmo tipo de inovações, nomeadamente a mobilização em rede, a organização horizontal e a atuação em "colectivos", cuja característica é não se fundamentar num sujeito contestatário unificado. Contudo, estas características que conferem a este e outros movimentos uma nova forma de mobilização e agir em público, poderão constituir um entrave à afirmação e à obtenção de resultados dos próprios movimentos sociais. Cefaï (2005: 135) adverte que a coordenação entre estes diferentes "coletivos" é problemática. Considera que por serem muito heterogéneos nas suas formas e recursos, organizações, estratégias ou ideais e amiúde demasiado dispersos para constituírem um objetivo muito focalizado e centros de contrapoder, não têm muitas vezes outra ambição além de informar, denunciar e reivindicar. Segundo Gohn (2014:13), os “coletivos" inspiram-se em várias fontes, consoante o grupo a que pertencem, não havendo, portanto, hegemonia ideológica ou mesmo utópica, motivando-os um sentimento de descontentamento, desencantamento e indignação contra a conjuntura económica e política". 
a um coletivo, ou a coletivos, convive com a comunicação personalizada e com a individualidade dos seus membros.

O que ocorreu no 15 de setembro, foram mobilizações públicas com a participação de anónimos, de personalidades políticas, de organizações diversas e de movimentos sociais e políticos mais ou menos instituídos, com uma pluralidade de vozes e grande heterogeneidade, com coletivos mais do que "um coletivo", com dispersão e uma natureza acontecimental, não cumprindo os habituais requisitos dos movimentos sociais convencionais (como os movimentos operários, feministas, pacifistas, ecológicos, estudantis, etc.). Os quadros de ação coletiva coexistiram e articularam-se com quadros de ação personalizados ${ }^{24}$.

Na manifestação do dia 15 de Setembro, ou no movimento QSLT, a ação coletiva do grupo QSLT propagou-se através das ligações tecnológicas a inúmeros utilizadores-receptores-emissores, expandiu-se na rede como ação conectada (ou como connective action organizationally enabled networks) e desaguou na rua como ação coletiva, ligando uns e outros pelo sentimento comum de descontentamento. A propósito, assinale-se que Bennett e Segerberg (2012: 745) reportam-se à transição entre ação conectada e ação coletiva:

"Nós exploramos a variedade de diferentes formas organizadas de protesto que usa a comunicação personalizada até o ponto em que elas entram na gama convencionalmente entendida como movimentos sociais. Esta é a zona de fronteira em que o que chamamos de ação conectada (connective action) dá lugar à ação colectiva" (Bennett e Segerberg, 2012: 745).

A ação conectada introduziu a sua modalidade de comunicação como um princípio organizador e a "sua lógica não exige um forte controle organizacional ou a construção simbólica de um 'nós' unido" (Bennett e Segerberg, 2012: 748) ${ }^{25}$.

Durante o tempo da sua ocorrência, enquanto acontecimento no espaço público em que aqueles que se encontram reunidos no mesmo espaço prestam mutuamente uma atenção conjunta, criouse um "espaço comum tópico" em consequência dessa ação conjunta. Acima de tudo, tratou-se de uma ação pública em resposta a um "campo problemático" definido e construído - a crise, a intervenção da troika, a austeridade. A ação pública decorreu no espaço público e estruturou-se mediante o critério da visibilidade - dar-se a ver e a ouvir - em protesto contra o problema público expresso no slogan: "Contra a austeridade. Que se lixe a Troika. Queremos as nossas vidas". A ação pública, ou a ação coletiva, não suprime nem exclui a ação conectada, pois a transição entre a rede e a rua processa-se quer entremeando quer coexistindo os dois tipos de comunicação, a comunicação interpessoal presencial e a comunicação tecnologicamente mediada.

24. Os protestos no quadro dos direitos públicos e políticos articulam-se, por exemplo, com os quadros da rejeição das desigualdades económicas e sociais que, por seu lado, se ramificam em configurações personalizadas (com modos inovadores de falar da sociedade e da política, com formas festivas e lúdicas, com expressões artísticas e novas formas de expressão que se inscrevem numa nova cultura pública contestatária e de protesto com implicação da experiência pessoal).

25. "As noted above, the emerging alternative model that we call the logic of connective action applies increasingly to life in late modern societies in which formal organizations are losing their grip on individuals, and group ties are being replaced by large-scale, fluid social networks (Castells 2000). These networks can operate importantly through the organizational processes of social media, and their logic does not require strong organizational control or the symbolic construction of a united 'we'” (Bennett e Segerberg, 2012: 748). 


\section{Ativismo em rede e na rua}

Nas manifestações que engrossaram na rua, a ação conjunta e as emoções que a acompanham sustentam, mediante essa convergência, um "nós" ou uma identidade coletiva efémera e precária, porque assente em relações deslassadas. Como M. Augusta Babo (2017: 133) observou, a propósito do ativismo em rede e na rua, "a aglomeração de rua cria uma identidade evanescente, fugidia, sem estratégia, sem destino". Mas, ao mesmo tempo, no movimento a que nos referimos, pode falar-se na emergência de um "nós" mais ou menos unido, em torno do grupo que criou e manteve a plataforma QSLT. A 1 de abril de 2013, colocam online um "esclarecimento" em que se afirmam como um coletivo, com modos de ação inovadores em relação aos convencionais ${ }^{26}$.

Com efeito, há uma continuidade e permanência no tempo do QSLT que organizou outros protestos e convocou novas manifestações a 2 de março de 2013. Como anteriormente, o movimento arroga-se uma composição plural:

"Um dos promotores do protesto disse à agência Lusa que a organizar a manifestação está um conjunto mais alargado de pessoas do que aquela que aconteceu a 15 de Setembro do ano passado" - e apelou a toda a participação - " "A todos os cidadãos e cidadãs, com e sem partido, com e sem emprego, com e sem esperança, apelamos a que se juntem a nós. A todas as organizações políticas e militares, movimentos cívicos, sindicatos, partidos, coletividades, grupos informais, apelamos a que se juntem a nós. De norte a sul do país, nas ilhas, no estrangeiro, tomemos as ruas'” (Negócios jng @ negocios.pt; 22 de janeiro de 2013) ${ }^{27}$.

26. “O QSLT é um fenómeno novo em Portugal e a sua definição escapa à generalidade dos analistas e comentadores. O seu formato e os seus modos de ação não encaixam nos formatos tradicionais de organização política e a sua atividade coletiva não é marcada por lideranças que facilitem mediatismos. Somos rostos comuns, de pessoas comuns que ativamente decidiram participar (...) Somos um grupo de pessoas que independentemente da sua filiação/simpatia ou independência partidária ou sindical decidiram que era urgente e necessário encontrar articulações e consensos em torno da análise política que se pode fazer do país sob intervenção da Troika. (...) Este coletivo de pessoas não tem fundadores, porta-vozes ou representantes. Tem membros que participam em discussões e em ações propostas em plenários, reuniões e pela net (...)".

27. "O movimento "Que se lixe a troika", que convocou a manifestação de 15 de Setembro, vai realizar a 2 de Março um protesto em várias cidades do país e no estrangeiro para contestar as medidas de austeridade do Governo. Num comunicado hoje divulgado, os promotores do protesto anunciam a manifestação para 2 de Março com o lema "Que se lixa a troika. O povo é quem mais ordena!

Um dos promotores do protesto disse à agência Lusa que a organizar a manifestação está um conjunto mais alargado de pessoas do que aquela que aconteceu a 15 de Setembro do ano passado e reuniu nas ruas milhares de pessoas.

'Na sequência das marcantes manifestações de 15 de Setembro de 2012 e das subsequentes ações no Palácio de Belém, Assembleia da República e da manifestação cultural de 13 de Outubro, somos hoje um lugar de encontro de várias correntes democráticas anti-troika. Não temos a pretensão de representar organizações ou sectores sociais. Queremos fazer a discussão e a confluência de iniciativas com vista ao derrube deste governo e de todos os governos colaboracionistas com os programas da troika', lê-se num comunicado do movimento.

Segundo os impulsionadores da iniciativa, a manifestação vai decorrer em várias cidades portugueses e no estrangeiro, estando o apelo a circular da rede social Facebook desde segunda-feira e já conta com a adesão de mais de duas mil pessoas.

'A todos os cidadãos e cidadãs, com e sem partido, com e sem emprego, com e sem esperança, apelamos a que se juntem a nós. A todas as organizações políticas e militares, movimentos cívicos, sindicatos, partidos, colectividades, grupos informais, apelamos a que se juntem a nós. De norte a sul do país, nas ilhas, no estrangeiro, tomemos as ruas', adiantam” (Negócios jng @negocios.pt; 22 de janeiro de 2013). 
Assim sendo, e mesmo tendo-se anteriormente aludido à efemeridade das adesões, é forçoso constatar que o movimento subsistiu no tempo, com vínculos e partilha de comunicação e compromissos entre os seus membros ${ }^{28}$. A caraterística que sobressai é o caráter global das manifestações: assim como a rede horizontaliza a comunicação e opera de todos para todos, também é feito um apelo a uma participação alargada e heterogénea na rua, o que explica, contrariamente ao movimento social tradicional, a pluralidade das adesões.

Há, portanto, um efeito da internet na modificação e rarefação da ação coletiva e que se repercute nos movimentos ocorridos na rua a partir das redes. É fácil mobilizar todos e é acessível perceber quais são as adesões a uma causa e aderir também. Surgem novas formas de constituir e defender causas coletivas, em situações que reconfiguram contextos de experiência pessoal e coletiva, na linha do que Castells denomina como 'cultura de autonomia' (Castells, 2012) ${ }^{29}$ e também como autocomunicação de massas (Castells, 2009) ${ }^{30}$. Esta última é uma comunicação global porque assenta nas redes de comunicação electrónica e, ao mesmo tempo, é um meio de comunicação pessoal em que a recepção se personaliza (há combinação e reformatação de qualquer conteúdo digitalizado e o receptor é produtor, sendo, por isso, como entende Castells, autocomunicação). As redes digitais tornam-se lugar de uma experiência individual de participação, mediante o ato de se ligar e partilhar e de se desligar, de acordo com uma lógica de troca de mensagens em que coexiste individualização e participação social, autonomia e dependência do todo. Ora, a autonomia na rede, em relação às instituições e organizações da sociedade, é adquirida tanto pelo ator individual como pelo coletivo (veja-se a facilidade da emergência do movimento QSLT).

Como nas manifestações do movimento QSLT, em 2012 e 2013, passa-se de mobilizações inseridas em quadros políticos, partidários e ideológicos definidos, para formas mais individualizadas de expressão de ideias, sentimentos, opiniões ou de "comprometimento expressivo" (Cardon e Granjon, 2013) sem estrutura partidária ou sindical. Há um fenómeno de individualização das e-mobilizações, no sentido em que as novas ligações tecnológicas reconfiguram as práticas de ativismo e, em certa medida, dispensam líderes e porta-vozes. As distinções entre informar e mobilizar, observar e participar, individual e coletivo, privado e público dissipam-se. Ao mesmo tempo, constata-se que o "militantismo em rede" (G. Pleyers, 2013) não conduziu à preponderância das interações virtuais - como as "e-táticas" e os "e-movimentos" a que se reportam Earl \& Kimport (2011) e Earl (2017) - que teriam tomado o lugar das manifestações no espaço urbano. A rua permanece o lugar do protesto, da reivindicação e da ação coletiva. E as manifestações e movimentos sociais convocados por associações ou organizações políticas, sindicais, partidárias e outras, continuam a ocupar o espaço público e mesmo a prevalecer.

28. Entre outras ações, o movimento "Que se Lixe a Troika! Queremos as nossas vidas" convocou igualmente uma mobilização "Todos os rios vão dar ao Carmo", para o dia 24 de abril de 2014.

29. "[...] capacidad de un actor social para convertirse en sujeto definiendo su acción alrededor de proyectos construidos al margen de las instituciones de la sociedad, de acuerdo con los valores e intereses del actor social [...]" (Castells, 2012: 220).

30. A rede digital favorece uma interatividade que articula autonomia e conectividade ao conjunto, individualização e integração no todo, e instaura o que Manuel Castells (2009) apelida de "auto-comunicação de massas" ou "comunicação de massa individual" (mass self-communication). Trata-se de um conceito antagónico nos seus termos: articula a individualidade e a autonomia com a massa. 


\section{REFLEX̃̃O FINAL}

Entre o mediativismo e os fenómenos de rua têm-se desenvolvido relações que requerem análise, assim como têm surgido novas experiências de ação coletiva e de ação pública, de participação individual no coletivo e novas formas de expressão pública. Nas redes criam-se novas práticas de mobilização e de protesto, e novas configurações comunicacionais e de sociabilidade, que apresentam efemeridade, dispersão e descomprometimento. Baseiam-se em relações mais heterogéneas, plurais e transitórias, com níveis mais ou menos elevados de individualização e desvinculação das organizações tradicionais. Ou seja, as mobilizações públicas e ações coletivas, que se ligam a novas práticas de participação e ao uso das redes digitais, tendem a ostentar formas individualizadas de "comprometimento expressivo", efemeridade, fragmentação, volatilidade, disseminação e globalização.

A comunicação electrónica, que se processa nos contextos reticulares, não requer a copresença de uns e outros, é dispersa, fragmentada e global. Por isso, as significações comuns construídas e os vínculos sociais que se desenvolvem nas interações comunicativas e na ação coletiva concertada, assim como as dinâmicas de associação e cooperação, deslassam-se nas redes, favorecendo a emergência das expressões individuais e da comunicação personalizada (na internet enviam-se mails, postam-se fotografias, música, vídeos, etc.). Há um enfraquecimento das convenções coletivas e das gramáticas da vida pública, que subsistem de modo mais frouxo e rarefeito, na própria medida em que prevalecem a individualização e a globalização. As ações partilhadas nas redes não chegam, assim, a produzir um "espaço comum" (Taylor, Quéré), enquanto lugar de constituição de uma vontade comum, de associação e de cooperação. Diferentemente da ação coletiva no espaço público, não se cria um espaço comum estruturado por uma atenção conjunta.

A rede é, por natureza, interativa, colaborativa, multimodal, a-centrada, de inclusão e de exclusão, global e de uso individualizado. A ação conectada detém modalidades mais individualizadas de adesão, emoção, expressão e interesse, embora, graças à Web 2.0, também se formem comunidades online (Wasko et al. 2004). A ação partilhada na rede pode, assim, em casos como as comunidades online ou as redes de ativistas, caracterizadas por quadros (frames) de ação personalizados que podem desenvolver interações fracas, mas que originam entendimentos ou causas comuns, configurar-se como ação coletiva ou quase-coletiva, sem propriamente ocasionar, como seu resultado, um sujeito coletivo ou um "nós" unido por uma atenção conjunta e consciência de si. Portanto, a resposta à questão inicial que coloquei será que a ação digital em rede desenvolve relações, partilhas e ligações que têm a sua própria lógica. Podem vir a desencadear ações coletivas, mas, enquanto ações conectadas dependentes das mediações tecnológicas detêm uma ecologia própria.

Há uma nova ecologia, de que Massimo Di Felice $(2012,2013,2017)$ dá conta, na qual as comunicações são reticulares e colaborativas, com uma nova condição habitativa integrando circuitos informativos, dispositivos e interfaces; sendo neste ecossistema, considera Di Felice, que deve ser encarado o ativismo em rede ${ }^{31}$.

31. "O ativismo digital e as formas de participação conectivas surgidas nas redes, embora em diversos casos exprimam objetivos e dinâmicas precisos, não somente não estão relacionados com identidades ou objetivos políticos, estranhos à disputa do poder, mas manifestam o advento de um processo de transformação da condição habitativa que 
A plataforma QSLT é uma modalidade de ação-comunicação coletiva organizada, integrada na rede digital. Na rede, pode a organização manter-se a estruturar a comunicação (como ação conectada em rede estimulada organizacionalmente; connective action organizationally enabled networks; Bennett e Segerberg, 2012), como pode dispersar-se e o caráter de comunicação personalizada e de adesão pessoal sobrepor-se. Uma vez na rua, a manifestação detém um caráter coletivo, que poderá ser mais ou menos organizado, mais ou menos dotado de uma identidade coletiva. Convém, porém, assinalar que a passagem da ação individual à ação coletiva não advém meramente da passagem da ação tecnológico-digital que é vertida para rua, mas depende da existência de formas coletivas de partilha, associação e organização; e de atenção conjunta e consciência de si como coletivo. Simultaneamente, e embora a ação coletiva se distinga da ação conectada, há situações de porosidade e permeabilidade em que vigora um regime híbrido, que pode oscilar da ação conectada para a ação coletiva, ou o inverso, ou apresentar concomitantemente traços das duas. As fronteiras entre o individual e o coletivo, o privado e o público, o coletivo e o conectado, a presença e a mediação, a desmaterialização e a (re)territorialização, a rede e a rua, são porosas e permeáveis. Donde, a reflexão sobre se a ação coletiva (e os movimentos sociais) e as formas de mobilização e comprometimento públicos, na era digital, estão a sofrer alterações, deve ser feita através da análise das mobilizações públicas que vêm ocorrendo. Só o exame das ações-comunicações-mobilizações nas redes e na rua permite dar conta dos quadros de ação pessoais e/ou coletivos. Nessa medida, a análise da ação conectada e da ação coletiva contribui para o estudo sobre o surgimento de novos coletivos, de novas causas comuns, de novos quadros de ação personalizados e da articulação destes a quadros de ação coletiva ou a novos movimentos sociais.

A banalização do uso das redes digitais sociais faz com que os atores sociais sejam utilizadores-receptores-emissores familiarizados com a ação conectada e que esta se imiscua na ação coletiva e intervenha nas práticas de mobilização pública. Estas mudanças em curso requerem exame, para se compreender as novas modalidades de ação coletiva (cívica e política) e as novas configurações de comunicação, ação e mobilização que se desencadeiam no espaço público.

\section{REFERÊNCIAS}

Aron, R. (1992). As etapas do pensamento sociológico. Lisboa: Dom Quixote.

Babo, I. (2013). As manifestações na Tunísia e no Egipto em 2010-11. A semântica dos acontecimentos nos media e o papel das redes digitais. Revista Análise Social, 209, XLVIII(4): 792-809. http://analisesocial.ics.ul.pt/?page_id=18

Babo, I. (2015). Espectadores e Públicos Activos. Lisboa: Editora Nova Vega.

Babo, I. (2017). Redes e Ativismo. In I. Babo, J. Bragança de Miranda, M. J. Damasio \& M. Di Felice (orgs.), Netactivismo. Lisboa: Edições Universitárias Lusófonas.

vê a passagem das formas do social sedentárias, geográficas, institucionais e políticas, para as formas tecnodiaspóricas, expressões de um novo tipo de ecossistema” (Massimo Di Felice, 2017:24). 
Babo, I. \& Silva, C. T. (2015). Public Sphere and Collective Action. the Portuguese Movement of the '15th September'. Mediterranean Journal of Social Sciences, $6(6$ S5): 425-433, dezembro. www.mcser.org/journal/index.php/mjss/article/view/8580

Babo, I. \& Silva, C. T. (2016). Redes sociais e mobilizações públicas. O movimento de 15 de Setembro. Atas do Congresso Internacional Ibero Americano em Investigação Qualitativa, 3: 182-192. http://proceedings.ciaiq.org/2016/index.php/ciaiq2016/issue/archive

Babo, M. A. (2017). Netativismo. Entre a rede e a rua. In I. Babo, J. Bragança de Miranda, M. J. Damasio \& M. Di Felice (orgs.), Netactivismo (pp. 127-136). Lisboa: Edições Universitárias Lusófonas.

Badouard, R. (2013). Les mobilisations de clavier. Le lien hypertexte comme ressource des actions collectives en ligne. Réseaux, Militantisme en réseau, 31(181): 87-117.

Benford, R. \& Hunt, S. (2001). Cadrages en conflit. In Raisons Pratiques 12, Les formes de l'action collective (pp. 163-194). Paris: Ed. EHESS.

Bennett, W. L. \& Segerberg, A. (2012). The logic of connective action. Information, Communication \& Society, 15(5): 739-768. Doi: 10.1080/1369118X.2012.670661.

Berger, P. \& Luckmann, T. (1985 [1966]). A Construção Social da Realidade. Petropolis: Vozes.

Blumer, H. (1969; 1986). Symbolic Interactionism. Perspective and Method. Berkeley and Los Angeles: University of California Press.

Cardon, D. (2011). La démocratie internet. Paris: Seuil.

Cardon, D. \& Granjon, F. (2013). Médactivistes. Paris: Sciences Po, Les Presses.

Castells, M. (2002). A sociedade em rede. Lisboa: Fundação Calouste Gulbenkian.

Castells, M. (2009). Comunicación y poder. Alianza Editorial, Madrid, España.

Castells, M. (2012). Redes de indignación y esperanza: Los movimientos sociales en la era de internet. Madrid: Alianza Editorial.

Cefaï, D. (1996). La construction des problèmes publics. Définitions de situations dans des arènes publiques. Réseaux, 75: 43-66.

Cefaï, D. (2001). Les cadres de l'action collective. In Raisons Pratiques, 12, Les formes de l'action collective: 51-97. Paris: Ed. EHESS.

Cefaï, D. (2005). Os novos movimentos de protesto em França. A articulação de novas arenas públicas. Revista Crítica de Ciências Sociais, 72: 129-160.

Cefaï, D. (2007). Pourquoi se mobilise-t-on? Les théories de l'action collective. Paris : La Découverte.

Cefaï, D. (2009). Como nos mobilizamos? A contribuição de uma abordagem pragmatista para a sociologia da ação coletiva. Dilemas:11-48.

Cefaï, D. \& Trom, D. (2005). Retour sur la sociologie des problèmes publics. Un entretien avec Joseph Gusfield. Secret/Public, (0): 209-222.

Dayan, D. (2000). Télévision, le presque-public. Réseaux, 100: 427-456. 
Dewey, J. (1929). Experience and Nature. [Versão electrónica], Chicago \& London: Open Court, 1925; revised edition, New York: Norton, 1929; London: Allen \& Unwin.

Dewey, J. (2010 a [1927]). Le public et ses problèmes. Paris: Folio, Gallimard (Traduzido do original inglês The Public and its Problems. In The collected works of John Dewey. The later Works, vol.2, 1925-1927. Southern Illinois University Presse.)

Dewey, J. (2010 b [1934]). L'art comme expérience. Paris: Folio, Gallimard (Traduzido do original inglês Art as experience. In The collected works of John Dewey. The later Works, vol.10, 1934, Southern Illinois University Presse.)

Di Felice, M. (2012). Netativismo: novos aspectos da opinião pública em contextos digitais. Revista Famecos, 19(1): 27-45. Porto Alegre.

Di Felice, M. (2013). Ser redes: o formismo digital dos movimentos net-ativistas. Matrizes, 7(2): 49-71. São Paulo: Universidade de São Paulo.

Di Felice, M. (2017). Net-ativismo e ecologia da ação em contextos reticulares. In Di Felice, \& R. Pereira (orgs.), Net-ativismo. Redes digitais e novas práticas de participação (pp. 13-28). Papirus Editora.

Dubet, F. (1990). Action et autoréflexion. In Raisons Pratiques 1, Les Formes de l'acion (p. 171-193). Paris: Ed. EHESS.

Earl, J. (2017). Possibilitando digitalmente a mudança social: aproveitando affordances e promovendo a mudança. In Di Felice \& R. Pereira (orgs.), Net-ativismo. Redes digitais e novas práticas de participação (pp. 53-64). Papirus Editora.

Earl, J. \& Kimport, K. (2011). Digitally enabled social change: Activism in the internet age. Cambridge: MIT Press.

El Oifi, M. (2011). O efeito Al Jazeera. Le Monde Diplomatique Brasil. www.diplomatique.org.br /artigo.php?id=936

Fornel, M. \& Quéré, L. (1999). Présentation, in Raisons Pratiques 10. La logique des situations: 7-32. Paris: Ed. EHESS.

Garfinkel, H. (1984 [1967]). Studies in Ethnomethodology. Cambridge, Polity Presse.

Goffman, E. (1973 [1959]). La mise en scène de la vie quotidienne. Paris: Minuit.

Goffman, E. (1974 [1967]). Les rites d'interaction. Paris: Minuit.

Goffman, E. (1991 [1974]). Les cadres de l'expérience. Paris: Minuit.

Gusfield, J. (1981). The culture of public problems: drinking-driving and the symbolic order. Chicago: University of Chicago Press.

Habermas, J. (1986 [1962]). L’Espace Public. Archéologie de la Publicité comme dimension constitutive de la société bourgeoise. Paris: Payot.

Koleva, S. (2013). Espace urbain et action citoyenne: rapports à géométrie variable. In G. Rouet (dir.), Mobilisations citoyennes dans l'espace public (pp. 17-29). Paris: L'Harmattan.

Lazega, E. (2014). Réseaux sociaux et structures relationnelles. Paris: PUF. 
Letonturier, E. (coord.) (2012). Les réseaux. Paris: CNRS Éd., Hermès.

Livet, P. (2002). Émotions et rationalité morale. Paris: PUF.

Mercklé, P. (2011). Sociologie des Réseaux sociaux. Paris: La Découverte.

Paperman, P. \& Ogien, R. (org.) (1995). La couleur des pensées: sentiments, émotions, intentions, Raisons pratiques. Paris: EHESS.

Pleyers, G. (org.) (2013). Réseaux. Militantisme en réseau, 31, 181.

Quéré, L. \& Pharo, P. (dir.) (1990). Les formes de l'action. Sémantique et sociologie. Raisons Pratiques 1. Paris: Ed. de l'EHESS.

Quéré, L. (2003). La structure de l'expérience publique d'un point de vue pragmatiste. In D. Cefaï \& I. Joseph (orgs.), L'Héritage du pragmatisme: Conflits d'urbanité et épreuves du civisme. Paris: L'Aube.

Quéré, L. (2015). Prefácio. In I. Babo, Espectadores e Públicos Activos (pp. 5-21). Lisboa: Editora Nova Vega.

Rouet, G. (dir.) (s.d.). Mobilisations citoyennes dans l'espace public. Paris: L'Harmattan.

Schütz, A. (1987). Le Chercheur et le Quotidien. Paris: Méridiens Klincksieck.

Snow, D. (2001). Analyse des cadres et mouvements sociaux. In Raisons Pratiques 12, Les formes de l'action collective (pp. 27-49). Paris: Ed. EHESS.

Snow, D. \& Benford, R. (1988). Ideology, Frame Resonance, and Participant Mobilization. International Social Movement Research, 1: 197-217.

Snow, D. A.; Rochford, B. Jr.; Worden, S. K. \& Benford, R. D. (1986). Frame alignment processes, micromobilization, and movement participation. American Sociological Review, 51(4): 464481.

Tilly, C. (1995). Contentious repertoires in Great Britain, 1758-1834. In M. Traugott (org.), Repertoires and cycles of collective action (pp. 15-42). Durham, NC: Duke University Press.

Thévenot, L. (1990). L'action qui convient. In P. Pharo \& L. Quéré (orgs.), Les formes de l'action (pp. 39-69). Paris: Éditions de l'École des Hautes Études en Sciences Sociales.

Trom, D. \& Zimmermann, B. (2001). Cadres et institution des problèmes publics. In Raisons Pratiques 12, Les formes de l'action collective (pp. 281-315). Paris: Ed. EHESS.

Wasko, M. M.; Faraj, S \& Teigland, R. (2004). Collective Action and Knowledge Contribution in Electronic Networks of Practice. Journal of the Association for Information Systems, 5(1112): 493-513. http://aisel.aisnet.org/cgi/viewcontent.cgi?article=1377\&context=jais

Weber, M. (1971 [1921]). Économie et société. Paris: Plon. 